Teologia i Moralność, Volumen 15(2020), numer 1(27)

doi: 10.14746/tim.2020.27.1.09

ORCID: 0000-0002-5167-0595

TOMASZ KRAJ

Pontifical University of John Paul II in Cracow

Theological Faculty

\title{
The Crises in the Church and the Problem of Virtue in Christian Life
}

The German "synodal way" comes in the context of clerical sexual abuse scandal in Germany. Although hardly could we say that the "synodal way" resulted from that scandal, it somehow affected the beginning of the "synodal way". ${ }^{1}$ The purpose of this paper is the reflection on the problem of the priestly sexual abuse in the Catholic Church and its consequences for the Church life, i.e. whether this sin should contribute to a new and radical change of the Church life and discipline, e.g. like that of "synodal way" or we can find some other solution(s) to the sinful human weaknesses within the long moral tradition of the Church.

The number of cases of alleged sexual abuse in Germany is estimated to be approximately 3700 over the course of 68 years. This number comes from a special document known as the M.H.G (Mannheim, Heidelberg, Gießen) Study which was made public in September 2018. The release of this document somehow influenced the decision of the Catholic Conference of German Bishops to start the so called "synodal way" within the German Church. ${ }^{2}$ It does not mean that all German bishops support either this solution for the crises in the Church in Germany or all the proposals known as the "synodal way". These proposals concern such issues as celibacy (as mandatory for all candidates to priesthood), the position of women in the Church (with possible their priestly ordination), and many aspects of sexual morality. Many

${ }^{1}$ Z. Ballinger Fletcher, German bishops' general secretary: The church should not fear the 'synodal way', https://www.americamagazine.org/faith/2019/11/21/german-bishops-general-secreta ry-church-should-not-fear-synodal-way [accessed: 11.02.2020].

${ }^{2}$ Ibidem. 
advocates of the "synodal way" expect significant changes in the life of the Church which have already been announced by His Eminence Reinhard Cardinal Marx, ${ }^{3}$ Archbishop of Munich and Freising, and President of the German Conference of Catholic Bishops, while Vatican Cardinal Marc Ouelet, Prefect of the Vatican Congregation for Bishops, warns German Bishops against decisions which could be incompatible with the requirements of Canon Law. ${ }^{4}$

One Polish bishop, the late Msgr. Taduesz Pieronek, expounded in 2013 that the Church is a community of sinful people, as well as the fact that the rate of various transgressions in the Catholic Church is lower than in other communities or social groups. ${ }^{5}$ This consciousness helps us to realize that sin has always been present in the Church, and that, however regrettably, it is a part of its reality. None the less, the main problem is the kind of measures the pastors together with believers intend to apply to overcome the present crisis. Should some moral requirements actually be abandoned, and Church discipline altered to make it more like other contemporary Christian communities or social groups, or should we preserve the heritage that has been particular to the Catholic Church?

Some lay Catholic professionals also took a part in the discussion of sexual abuses in the American Church and they expressed their concern. One of the results of that concern was the "Reflection on the Relationship Between the Lack of Asceticism and Sex Abuse" prepared by psychologist Richard Cross, $\mathrm{Ph}$. D. with the collaboration of Daniel Thoma, Ph. D. and sponsored by the Linacre Institute and The Catholic Physicians' Guild of Chicago (cfr. Cross, Thoma 2006, p. 1-116) ${ }^{6}$ was given a significant title: "The Collapse of Ascetical Discipline And Clerical Misconduct: Sex and Prayer." One of its conclu-

${ }^{3}$ T. Kycia, Kard. Marx: Zmienimy moralność seksualnq. To nasza droga (Kard. Marx: We are changing sexual morality. This is our way), https://www.fronda.pl/a/kard-marx-zmienimy-moralnosc-seksualna-to-nasza-droga, 123784.html [accessed: 11.02.2020].

${ }^{4}$ J.Luxmoore, German Catholicscompletefinalpreparationsfor 'synodalway', https://www.ncronline.org/news/world/german-catholics-complete-final-preparations-synodal-way. [accessed: 11.02. 2020].

${ }^{5}$ M. Mańkowski, Biskup Tadeusz Pieronek o pedofilii: Była, jest i będzie. Żadna siła nie powstrzyma człowieka (Bishop Thaddeus Pieronek about pedophilia: It has been, it is, and it will be. There is no power to restrain anyone), https://natemat.p1/50469,biskup-tadeusz-pieronek-opedofilii-byla-jest-i-bedzie-zadna-sila-nie-powstrzyma-czlowieka [accessed: 11.02.2020]. It is also true that the abuses committed by Church members, especially clerics, are overrepresented in the media, particularly in comparison with similar abuses committed by the members or officials of other communities or social groups.

${ }^{6}$ In the Preface to the Reflection Richard Cross Ph.D. is identified as a consulting psychologist from Leominster MA, and a contributor to the Linacre Quarterly. His „original perspective on the relationship of the collapse of the asceticism to the clerical pederast crisis is widely recognized." (Cross, Thoma 2006, p. 3). Daniel Thoma, Ph.D. is identified as his collaborator in the research and literature review. 
sions refers to the Second Vatican Council's proposal concerning the openness of the Church to the world. However, the misunderstanding of this openness by some part of the clergy (especially considering the coincidence of the sexual revolution's sudden burgeoning in the time frame right after the Council) resulted in the collapse of traditional ascetic discipline, and subsequently, in a marked increase in the sexual abuse of minors by clergy. ${ }^{7}$ The American reflection presented suggests that Church discipline helps to overcome sinful weaknesses, while abandonment of such discipline with a desire to follow some worldly proposals which have very little to do with the moral teaching of the Bible and Catholic Tradition only leads to an increase in such sinful weaknesses. It is significant that contemporary German "reformers" of the Catholic Church pay so little attention to this American reflection, and especially to the concepts of discipline and the role of virtue in the Christian life.

\section{The specificity of Christian vocation and the Christian life}

Many people are looking for the roots of the present crisis in the Western Church. For some of them the old pastoral methods and approach, and particularly the moral teaching of the Church, appear to have been wrong. They want to replace them with something new which has never previously existed in Catholic Tradition. They say that new times and new challenges require new solutions. Nevertheless, some basic questions should be answered before we decide to change pastoral rules, and introduce new proposals for priests, couples, women, and other members of the Church. Those who are sent, like the Apostles, the pope, bishops, and priests, while making such a decision, should always consider St. Paul's words that we should proclaim and follow the Gospel in such a way "that the cross of Christ might not be emptied of its meaning" (1Cor 1:17).

Although we want to find proper solutions for the Church in crisis, we should not forget that the community is always made up of individuals who decide on its internal life. This means that we should not overestimate the communal dimension of the Church and neglect the individual lives and ef-

${ }^{7}$ There are some other causes mentioned too. One of them concerns the efforts by communist to ruin the Catholic Church in the USA with the help of gay men as candidates for the priesthood. Cfr. G. Górny, Komunistyczna agentura od lat niszczy Kościól od wewnątrz (Communist agents have been breaking the Church down from inside for years), https:/www.pch24.p1/grzegorz-gorny-komunistyczna-agentura-od-lat-niszczy-kosciol-od-wewnatrz,62525,i.html [accessed: 11.02.2020].

${ }^{8}$ All biblical quotations come from The New American Bible, Revised Edition provided by United States Conference of American Bishops: http://www.usccb.org/bible/books-of-the-bible/ [accessed: 11.02.2020]. 
forts of its members. This important approach was underlined by Madeleine Delbrêl (1904-1964), a famous French writer and convert, whose beatification is currently under way, who compared the community to a forest: the forest is strong when the trees are strong, the trees are strong when the roots are strong, and the roots themselves are individuals. ${ }^{9}$ Hence, if we wish to have a strong Church community, we will need strong, reliable individuals who are faithful to the truth about man and his moral conduct. This is also the reason why we will concentrate here on the individual dimension of Christian life as it relates to the present crises in the Church.

The main question which needs to be answered is: What is the main purpose of the Christian life? What do I as a Christian need to do? The answer is: To be a Christian means to follow Jesus; to make my life like His; to imitate Christ in my life. ${ }^{10}$ However, the overall human condition differs from that of Jesus, because He was like us in every aspect of His life apart from sin (cfr. Heb 4:15). Thus, the main problem of Christian vocation is to conquer sin, which is somehow "responsible" for our moral weaknesses - sexual problems included - and hinders our following Jesus. Although we cannot accomplish this important task on our own ("without me you can do nothing" John 15:5), it does not mean that we have nothing to contribute to our own salvation. "If anyone wishes to come after me, he must deny himself and take up his cross daily and follow me" (Lk 9:23).

To take up our crosses and follow Jesus is a very demanding task. As St. Paul writes to the Romans: "For I know that good does not dwell in me, that is, in my flesh. The willing is ready at hand, but doing the good is not. For I do not do the good I want, but I do the evil I do not want. Now if [I] do what I do not want, it is no longer I who do it, but sin that dwells in me. So, then, I discover the principle that when I want to do right, evil is at hand. For I take delight in the law of God, in my inner self, but I see in my members another principle at war with the law of my mind, taking me captive to the law of $\sin$ that dwells in my members." (Rom 7:18-23). That is why we need the liberation which we cannot gain without God's help. However, we need to cooperate within the process of our liberation - and this is exactly what Jesus says about the daily carrying of our cross while following Him. Without God's help we can do nothing; with his help we still have much to do because He does not

9 “«Il faut savoir être seul avec Dieu pour faire une communauté. C'est comme une forêt qui est belle, si chaque arbre est fort et a des racines puissantes: ces racines sont solitaires» (Madeleine Delbrêl)". Quoted by J. Lafrance 1997, p. 119.

${ }^{10}$ This task mirrors the fundamental truth of Christian anthropology that man was created in the image and likeness of God, which is the starting point of his conscious activity as a Christian, as well as the goal of his or her life i.e. the point of arrival. To be created in His image is a gift from God; for us to respect this gift properly is the most important human and Christian task. 
want to save us without us, i.e. without our active participation in our salvation. There is a long tradition within the Church mirrored in Catholic Theology which shows us how a believer should change his or her life to follow Jesus and imitate Him, and thus fulfill God's plans concerning his or her salvation. This tradition relates to virtue.

\section{The role of virtue in the Christian life}

The history of philosophy and theology demonstrates some changes in the understanding of virtue. ${ }^{11}$ However, the most convincing description of virtue is that provided by St. Thomas Aquinas. Not only is it fully compatible with the moral teaching of the Church, but it is also confirmed by the common human moral experience. Thus while preserving its relevance and timeliness today, this description helps us to better understand the present moral crises in the Church, as well as helping us to find a good solution to it. ${ }^{12}$

Virtue consists in the perfection (i.e. in goodness) of human conduct. It gives us the motivation to perform morally good acts. After some practice of virtue we are inclined do these kinds of acts willingly, with greater ease and even joyfully. It also helps us in a significant way to overcome sin and its effects, as well as helping us to follow Jesus, and imitate Him. Thus it seems that this is exactly the virtue which is the most desirable Christian capacity. However, the problem is not that we do not want to be virtuous; it is rather the way in which man acquires virtue that creates problems. It is not an easy task to become a virtuous person. Virtue is demanding. Although God helps us with His grace, He (the same as in what concerns our salvation) none the less still requires our own moral efforts: He helps our efforts but He does not replace them (grace builds on nature, i.e. on that which man contributes to the process). That is why it is so important to correctly understand how virtue

\footnotetext{
${ }^{11}$ The best known are works by Alasdair MacIntyre, especially his "After Virtue".

${ }^{12}$ We need to be careful when somebody says that this concerns some old and outdated ethical theory, and we have already abandoned many medieval convictions, scientific among others. Nevertheless there are two specific types of academic disciplines, i.e. experimental science vs. philosophy and theology, each of which explores its subject in its own specific way. In the case of experimental science its subject is explored progressively, i.e. each new period has newer, usually better methods of exploration which give new opportunities to better recognize the subject and to verify and possibly reject old convictions. In the case of non-experimental disciplines like philosophy and/or theology, their subjects are based on immutable basic truths, i.e. there continues to be incremental progress, but, contrary to experimental science, there cannot be any alteration of underlying foundations. That is why some observations and assertions (e.g. those of Plato and Aristotle) preserve their value despite the passing of centuries. The same concerns the philosophy and theology of St. Thomas Aquinas.
} 
works: what the human part is in it, and what is not quite yet a virtue, although it might be something similar to one.

In order to properly understand our own role in achieving virtue, we need to realize that there are two main competing theories of virtue today. One, which refers to Aristotle and St. Thomas Aquinas; and the second, which refers to John Duns Scotus and Immanuel Kant. The latter could be labelled the intellectualist concept of virtue (cfr. Cessario 2009, p. 80, 206).${ }^{13}$ It admits the exclusive role of human intellect in moral conduct since the human intellect recognizes what is good and determines what actions to take. Thus the intellectualist theory of virtue underestimates the importance of human bodily appetites and inclinations in moral conduct. It does not recognize the limitations of the intellect's sovereignty over human appetites and inclinations, especially if they become disordered. This concept of virtue might be expressed by the assertion that if man knows what is good, he is also able to accomplish it.

Meanwhile the common experience tells us something different. The phenomenon of human vices show that the intellectualist concept of virtue does not mirror our everyday moral experience. In some situations it might be more difficult to verify this experience, however, it is quite easily verified when we consider addictions, i.e. the situation of disordered human appetites and inclinations. We can easily imagine the situation of people addicted to alcohol, drugs, or pornography. They know perfectly well what is good, and what they should choose and do. In spite of that knowledge they regularly do something different. This is because of their inclinations: emotional inclinations, bodily inclinations, and, because of human unity of body and soul, even spiritual inclinations. When these inclinations become disordered the person's capacity for good action itself becomes impaired, and we witness human misery. This experience shows us that for morally good conduct to abide in us, it is necessary for knowledge of what is good to be accompanied by our correctly ordered appetites and inclinations.

This not to say that every action of an addicted person will always be morally wrong or that such a person cannot do anything good at all. They can sometimes do what is good and expected from them. However, this involves only their separated, isolated acts, which do not mirror the real state of their minds and wills. They are not virtuous persons, although they may sometimes do what is morally good even in the field affected by their vices. In spite of these singular good acts we cannot rely on these people. Although they sometimes can be sober, we normally do not allow alcoholics to work as pilots or

13 This concept in its principal assumptions may be traced to Socratic convictions that the knowledge of what is good is sufficient to that good (Cfr. MacIntyre 1991, p. 21-22). 
bus drivers. There is something very important missing in their lives. What is missing is a good habitus.

This observation is also confirmed by Jacques Maritain's student and collaborator Yves R. Simon who writes: "In fact, without confirmed habits, I do not see how anybody's virtue could be trusted. Take, for instance, the case of a man who after years of dissipation undergoes a moral conversion. You know him well, and you have every reason to believe that he is sincere, that his change of mind and heart is genuine. But you still will not let him drive the school bus the next day. While he may indeed never take another drink for the rest of his life, in the beginning you cannot be completely sure. What you want to do is to give the man time to build up the habit of moderation, and he cannot do that simply by abstaining from drinking alcoholic beverages for twenty four hours. [...] In other words, the existential readiness of the virtue of temperance requires the habit of moderation as its instrument. Without firm moral resolve, an alcoholic cannot stop being alcoholic. But whatever in his metabolism, nervous system, or psychological make-up drove him to drink is still there the day after his decision to quit. Thus in order to know that he has finally conquered these forces behind his addiction, known to defy even the strongest wills, what he also needs is a steady practice of moderation over a decent period of time." (Simon 1986, p. 77). ${ }^{14}$

Thus moral virtue requires something more than knowledge about what is good and even something more than singular good acts. It requires the development of good habit, habitus, something special which man "has". Habitu s is a Latin word, a participle of "habere": to have. It is a stable, lasting human disposition. Romanus Cessario, OP names it as "a definite ability for growth through activity" (Cessario 2009, p. 34). Nevertheless, as we noticed above, habitus might be good or bad (cfr. Cessario 2009, p. 40). Virtue needs good habitus, but its acquisition requires time and great personal efforts. Habitus proper to virtue results from constantly repeated good choices. This is the proper way for a man to gain a good disposition. Dietrich von Hildebrand notes also that habitus proper to virtue does not result from some "mechanical" or "automated", i.e. unconscious repetition of particular acts. Habitus is neither a result of some "moral" training nor some temperamental dispositions which do not depend on our conscious choices: "we have to distinguish virtues and vices from mere temperamental dispositions such as a phlegmatic or sanguine temperament, loquacity or taciturnity. These features are also habitual and lasting elements, and, moreover, they have an outspoken qualitative char-

${ }^{14}$ Although Simon suggests that, in contrast to the principles of contemporary psychology, an alcoholic may stop being an alcoholic, this observations is not relevant to what he says here about moral virtue. 
acter. They have thus be the more easily confused with virtues. But in reality they differ fundamentally from virtues. Neither knowledge of a certain sphere of goods, nor a response to this sphere, is to be found in these mere temperamental dispositions. Like mere urges, they possess no genuine intentionality. To be vivacious implies patently no knowledge of good and no attitude toward it, whereas every virtue presupposes the knowledge of a realm of goods and implies a general superactual response toward it" (Hildebrand 1953, p. 363).

Thus, St. Thomas Aquinas, together with his contemporary commentators, provides us with the principal elements that moral virtue consists of. Some of them are of the spiritual nature, and some less, but all of them are intertwined in the corporeal and spiritual unity of the human person. Knowledge about values plays a very important role in given circumstances, and their relationship to the main human values. Theology, in turn, emphasizes the connection between human fulfillment and basic human goods as being among those main human values (Cfr. Cessario 2009, p. 80). However, this knowledge, and the order of our intellect that is based on this knowledge, are not sufficient to ensure the endurance of good human behaviors. Good habitus is also very important as well as some time to gain both: the habitus and the proper knowledge. In the Christian life to these irreplaceable elements God adds His grace which accompanies His children's virtuous efforts to follow Jesus and imitate Him. Along with this grace we obtain various kinds of infused virtues which help us to fulfill our vocations.

\section{What might be the problem of the Christians in Germany?}

Being far from passing judgement on others, we still ask what might be those principals that cause some Church communities to decide to leave the traditional Christian life, and to adopt new moral rules unacceptable to the Magisterium and Catholic moral tradition. Priestly misconduct in the USA suggests that it might be a result of false or misplaced openness to the world, especially in what concerns sexual morality: the acceptance of some gender and LGBT proposals, ${ }^{15}$ a postulate to abandon contraception, celibacy in the priestly life, and marriage as a unity of a man and a woman. ${ }^{16}$ If this is so,

${ }^{15}$ Cfr. G. Górny, Biskupi ukraińscy wysłali do biskupów niemieckich „, braterskie upomnienie” w sprawie drogi synodalnej (The Ukrainian bishops sent the German bishops a „fraternal admonition" concerning the synodal way), https://wpolityce.pl/kosciol/485900-braterskie-upomnienie-doniemieckich-biskupow [accessed: 11.02.2020].

${ }^{16} \mathrm{We}$ could also add here the already accepted practice of administering Holy Communion to divorced and remarried people who do not live in chastity, as another example of presumed human inability to follow traditional moral requirements concerning human sexuality. 
another question arises: Why is such inability to follow Catholic sexual ethics acknowledged? It seems that the description of moral virtue provided by St. Thomas Aquinas and his commentators gives an answer to this question. It is particularly well seen when we consider the virtue of prudence.

Prudence is one of the most important virtues. We will consider here neither the modern nor colloquial understanding of prudence which became „the power to shape the future to conform to my purposes", and thus has little to do with its classic philosophical and especially theological meanings. ${ }^{17}$ Prudence is the virtue which perfects practical reason (i.e. the reason employed in human actions) in such a way that not only can the human person choose the real good in particular circumstances, but also that good which contributes in the best way to the good of the human life as a whole (cfr. Melina, Noriega, Pérez-Soba 2008, p. 352). St. Thomas describes how it happens; how prudence works in the Christian life.

There is here again an important difference between the description of prudence in Kantian and post-Kantian ethics, and that which is rooted in St. Thomas Aquinas' theology. In the first case "the categories of practical reason intervene at each discrete moment of moral choice, but their normative character derived from sources which remain a priori and, therefore, independent of cumulative human experience and inclinations. [...] Aquinas insists that the moral virtues and prudence operate according to a kind of synergy, that is, they exercise a causal influence on each other" (Cessario 2009, p. 77). According to ethics rooted in modern philosophy, prudence preserves its intellectualist character. It works independently of other human dispositions, especially of other human virtues which relate to well-ordered human inclinations. As a result, "given a sovereign view of conscience, only two alternatives are possible. On the one hand, conscience can assume the role of a dictator and judge, employing psychological guilt as a principal instrument for enforcing its commands. Or, on the other hand, conscience, especially when confronted with a strong but disordered appetite, can issue an exemption from the observance of any moral norm which otherwise would conflict with the untoward craving of appetite. To implement the second alternative supposes a kind of autonomy alien to New Testament liberty. Since the first alternative can result in much psychic and spiritual distress, the option for 'freedom' through exemption naturally holds a much broader appeal. Not a few contemporary moral theologians stand ready to allow a complete range of erratic behavior, especially in the area of sexual morality, on the basis that strong, felt dispositions justify conscien-

17 Cfr. Anon, prudence, https://dictionary.cambridge.org/pl/dictionary/english/prudence [accessed: 11.02.2020]. The quotation in the text comes from: Slade 1999, p. 63. See also: Melina, Noriega, Pérez-Soba 2008, p. 350-351. 
tious exceptions in a given case or in an entire class of cases" (Cessario 2009, p. 81$){ }^{18}$

It seems that in this important paragraph Cessario describes the moral situation which very accurately mirrors what happens in the case of the nonvirtuous person, i.e. a person without well-ordered appetites and inclinations known also as a good habitus, especially when he or she lives in the contemporary secularized society and does not do much in order to preserve his or her Christian identity. If we also consider what St. Thomas says, i.e. that "the enduring human ability to live the virtuous life always requires the continued presence of divine cooperative grace" (Cessario 2009, p. 75), and if we consider the lack of piety in the secularized Western Church communities whose members, because of their absence from Sunday Masses, and their problems with the sacrament of penance, i.e. the problem that they voluntarily choose to remain without the grace of God - we realize that this is a specific moral situation in their life: the situation of a Christian who stands before some moral requirements - those which come from the New Testament and/or the natural law - and has no power whatsoever to follow them. In such a situation the repudiation of at least some of them together with the adoption of their "secularized" version, which is incompatible with the teaching of Church Tradition and the Magisterium, seems to many (even to some pastors) a good solution. This is because it is not possible for anybody to require from somebody something which is patently unfeasible. To make this solution even more attractive, it has been labelled as humanitarian and progressive, or more "ecclesiastically", a "synodal way". However, the real solution to our moral problems is not to escape from the truth about man and his relationship to God and the Church as Jesus desired, but to return humbly to God and His idea of our salvation which covers all: His grace, our prayers and sacramental life, and our moral efforts - especially efforts related to virtue

\section{The task for pastors and theologians - bishops, priests, and lay people}

A crisis usually requires that some questions be posed, and that reflection concerning the future be intensified. During many years after World War II the Church in Germany was open to other Churches, and was very helpful to foreign priests. Some of them, while pursuing academic activities (mostly German language courses), served in German parishes. Not a few of them provid-

18 The "psychic and spiritual distress" mentioned by the author in the quoted paragraph relates to the philosophical problem of ontological truth (postponed completely by modern philosophy) and its role in morals. See: Pieper 1989; Kraj 2010, p. 214-240. 
ed such services for years. They have witnessed how the Church in Germany has changed. On the one hand it has given us great theologians, bishops, and even a Pope, but on the other hand it has now arrived at the brink of a chasm. Isn't it a proper time to reflect on its current condition in the context of the breadth of Church Tradition and the common Christian moral experience something similar to the reflection of the American lay people on the crisis which resulted in priestly misconduct and sex abuses? This kind of reflection could help the Church in Germany as well as other Church communities which may be going through similar times of crisis or are close to them.

It seems good to answer some fundamental questions: What is the moral life and how does it work? What does the Church teach about it? Among many topics within that teaching we may also find the moral virtue which enables us to follow Jesus, and to imitate Him and His humanity in our own lives. St. Paul helps us to understand that for our renewal in Christ: "you should put away the old self or your former way of life, corrupted through deceitful desires" (Eph 4:22). Also St. John in his First Letter warns Christians against living according to the world: "Do not love the world or the things of the world. If anyone loves the world, the love of the Father is not in him. For all that is in the world, sensual lust, enticement for the eyes, and a pretentious life, is not from the Father but is from the world. Yet the world and its enticement are passing away. But whoever does the will of God remains forever." (1 John 2:15-17).

Since human nature does not change, we face the same problems as our ancestors and all former generations of Christians. To be saved we also need to follow the moral teaching of the Church which relates to virtues as described, not only by St. Thomas and his commentators, but also by so many Christian teachers and apostles, although some of them did not use the very notion of virtue. Virtue requires some effort, however God helps us with His grace and the virtues He infuses in us when we remain in His grace.

Being conscious of how important virtues are in our life we need to learn about them and to achieve them. It is a great effort which requires time and perseverance, self-discipline, and self-denial, i.e. sacrifice. Since it needs time to be formed, it should be made an irreplaceable part of Christian education. You cannot have virtuous adult believers if you do not have young people who understand some basic rules of moral life, and who want to follow them. You cannot have virtuous adult believers if you do not have virtuous educators.

Virtue also brings about the proper ordering of human emotions. It helps our life to be directed by reason rather than by emotions. Thus, virtue helps us to follow what is rational, and compatible to the real human good. Virtue also influences our moral cognition: we know better and more easily what is good and what is evil; what we should do and what we should avoid. It changes the human life to its very depth - to live a virtuous life is something different from 
other forms of human life. The virtuous life brings joy and happiness, particularly when we do something good. However, it is also a demanding way of life, like the whole Christian life and vocation in their entirety. The virtuous life contributes to the main task of the Christian life: to follow Jesus and to imitate Him. This is also the main reason why this kind of life is so hated by God's enemies, of which the Ruler of this world is the most dangerous.

If we are looking for solutions to the crises in the various Church communities, we need to remind ourselves of the basic rules of good Christian life which should be followed or repeated in our lives. We cannot follow the proposals given to us by the world, of which the adoption of "new" sexual ethics is only an example. We also need to realize that our vocations, if they are to be fulfilled properly, require a long-lasting effort from us, supported by God's grace to which we must be open with our prayer and sacramental life - first and foremost the sacraments of penance and Holy Communion. Christian life is this kind of reality where usually nothing happens "instantly". Everything requires effort on our part, and this is our participation in the cross of our Lord.

This consciousness results in a great responsibility, which pastors and theologians should take upon themselves. As Cessario notes "in addition to pointing out the obstacles to a virtuous life [...] theologians should also accept the responsibility of explaining how the believer can fulfill the demands of virtue enunciated by Church teaching. Otherwise, instead of a Christ who transforms culture, we proclaim that our culture conquers Christ. In the work of evangelization, there exists no room for compromise on what the grace of Christ can accomplish in anyone, no matter what his or her state or condition may be" (Cessario 2009, p. 66). If the Church in Germany succeeds in its present challenges, i.e. if it remains faithful to the truth of man and to the Church's teaching concerning the virtue of chastity, it will be a sign of hope for it for the future, and also for other Church communities which may face similar situations of crises in their faith and/or hope and/or love.

\title{
KRYZYS W KOŚCIELE A PROBLEM CNOTY \\ W ŻYCIU CHRZEŚCIJAŃSKIM
}

\author{
Streszczenie
}

Jesteśmy świadkami kryzysu w niemieckim Kościele. Rozważane są propozycje porzucenia tradycyjnej nauki Kościoła o ludzkiej seksualności i przyjęcia norm nawiązujących do modnych dziś na Zachodzie ideologii, takich jak gender i LGBT, oraz większej „wolności” seksualnej. Te nowe propozycje stanowią część tzw. drogi syno- 
dalnej. Powstają pytania o przyczyny kryzysu. Autor widzi wśród nich pominięcie zagadnienia cnoty w postępowaniu moralnym chrześcijanina oraz oparcie się na niewłaściwej (co widać zwłaszcza w przypadku roztropności) intelektualistycznej koncepcji cnoty odwołującej się do Immanuela Kanta. W koncepcji tej świadomość powinnego dobra moralnego wystarcza do jego realizacji. Koncepcja ta pomija znaczenie ludzkich pragnień i skłonności w działaniu moralnym i prowadzi do sytuacji, w której pomimo wiedzy człowiek nie jest w stanie zrealizować poznanego dobra. Wina za ten stan rzeczy jest przypisywana moralnym zobowiązaniom, które jako niedające się zrealizować należałoby porzucić. Autorem innego, realistycznego opisu cnoty jest św. Tomasz z Akwinu. Pomocą w rozwiązaniu współczesnych problemów moralnych jest ponowna refleksja nad realistyczną koncepcją cnoty i jej roli nie tylko w wypełnianiu chrześcijańskiego powołania, ale także w chrześcijańskim wychowaniu.

Słowa kluczowe: nadużycia moralne duchownych; „droga synodalna”; powołanie chrześcijańskie; cnota; Kant; Akwinata; habitus; roztropność; wychowanie

Keywords: priestly misconduct; "synodal way"; Christian vocation; virtue; Kant; Aquinas; habitus; prudence; education

\section{BIBLIOGRAPHY}

Cessario R., The Moral Virtues and Theological Ethics, Notre Dame, Indiana 2009.

Cross R., Thoma D., The Collapse of Ascetical Discipline and Clerical Misconduct: Sex and Prayer, "Linacre Quarterly" 1 (2006), p. 1-116.

Hildebrand D. von, Christian Ethics, New York 1953.

Kraj T., Granice genetycznego ulepszania czlowieka (Accepted limits of genetic enhancement in humans), Kraków 2010.

Lafrance J., Un chemin de confiance: Thérèse de Lisieux, Paris 1997.

MacIntyre A., A Short History of Ethics, London 1991.

Melina L., Noriega J., Pérez-Soba J.J., Camminare nella Luce dell'Amore. I fondamenti della morale cristiana, Siena 2008.

Pieper J., Living the Truth, San Francisco 1989.

Simon Y.R., The Definition of Moral Virtue, New York 1986.

Slade F., Was Ist Aufklärung? Notes on Maritain, Rorty, and Bloom With Thanks But No Apologies to Immanuel Kant, in: The Common Things: Essays on Thomism and Education, ed. D. McInerny, Washington D.C. 1999.

\section{From the Internet}

The New American Bible, Revised Edition, http://www.usccb.org/bible/books-of-the-bible/ [accessed: 11.02.2020].

Anon, prudence, https://dictionary.cambridge.org/pl/dictionary/english/prudence [accessed: 11.02. 2020].

Ballinger FletcherZ., German bishops 'general secretary: The church should notfear the 'synodal way', https://www.americamagazine.org/faith/2019/11/21/german-bishops-general-secretary-chu rch-should-not-fear-synodal-way [accessed: 11.02.2020]. 
Górny G., Biskupi ukraińscy wysłali do biskupów niemieckich „,braterskie upomnienie” w sprawie drogi synodalnej (the Ukrainian bishops sent to German bishops „fraternal admonition” in what concerns synodal way), https://wpolityce.pl/kosciol/485900-braterskie-upomnienie-doniemieckich-biskupow [accessed: 11.02.2020].

Górny G., Komunistyczna agentura od lat niszczy Kościót od wewnątrz (The communist agents have ruined the Church from inside for years), https://www.pch24.pl/grzegorz-gorny--komunistycznaagentura-od-lat-niszczy-kosciol-od-wewnatrz,62525,i.html [accessed: 11.02.2020].

Kycia T., Kard. Marx: Zmienimy moralność seksualna. To nasza droga (Kard. Marx: We are changing sexual morality. This is our way), https:/www.fronda.pl/a/kard-marx-zmienimy-moral nosc-seksualna-to-nasza-droga, 123784.html [accessed: 11.02.2020].

Luxmoore J., German Catholics complete final preparations for 'synodal way', https://www.ncronline.org/news/world/german-catholics-complete-final-preparations-synodal-way [accessed: 11.02. 2020].

Mańkowski M., Biskup Tadeusz Pieronek o pedofilii: Była, jest i będzie. Żadna siła nie powstrzyma czlowieka (Bishop Thaddeus Pieronek about pedophile: It was, it is and it will be. There is no power to stop a man), https://natemat.pl/50469, biskup-tadeusz-pieronek-o-pedofilii-byla-jest-ibedzie-zadna-sila-nie-powstrzyma-czlowieka [accessed: 11.02.2020].

Tomasz KRAJ - kapłan archidiecezji krakowskiej, profesor UPJP II w Krakowie, kierownik Katedry Teologii Życia na Wydziale Teologicznym tej uczelni. Zainteresowania naukowe to bioetyka w jej wersji teologicznej, etyka cnoty, prawo naturalne. 